\title{
高齢者の身体能力認識と転倒について
}

\section{Elderly People's Physical Strength Awareness and Falling}

\begin{tabular}{|c|c|c|c|}
\hline 直 1,2$)$ & 貴大 ${ }^{1)}$ & 誠一1) & 田中 \\
\hline 悦子3) & 高木麻里子 ${ }^{3)}$ & 栄里3) & 対馬 \\
\hline
\end{tabular}

TOSHIMICHI SUGIHARA, RPT, MS ${ }^{1,2)}$, TAKAHIRo GO, RPT ${ }^{1)}$, SEIICHI MISHIMA, RPT, MS ${ }^{1)}$, MOTOTAKA TANAKA, RPT ${ }^{3)}$, ETSUKO SHIBATA, RPT ${ }^{3)}$, MARIKO TAKAGI, RPT ${ }^{3)}$,

ERI KIKUCHI, RPT ${ }^{3)}$, EIKI TSUSHIMA, RPT, M.Sc. ${ }^{4)}$

1) Department of Physical Therapy, Yamagata College of Medical Arts \& Sciences: 367 Mizushita Maeakashi, Yamagata-shi, Yamagata 990-2352, Japan. TEL +81 23-645-1571

2) Department of Physiology, Yamagata University school of Medicine

3) Department of Rehabilitation, Obanazawa Hospital

4) Department of Physical Therapy, Hirosaki University School of Health Science

Rigakuryoho Kagaku 20(1): 13-16, 2005. Submitted Aug. 25, 2004. Accepted Oct. 12, 2004.

ABSTRACT: There is a real danger that an inadequate movement strategy invites the prospect of falling in elderly people lacking proper physical strength awareness. In this report we examined the factors regarding falling related to physical strength awareness in the elderly using the recognized 'functional reach test', in the clinic. This was done with the objective of constructing an index for predicting falls with high accuracy. We used 88 healthy elderly people that were able to perform the trial and who had no impediments whatsoever in daily life. After subjects declared their estimate values for the 'functional reach test' actual measurements were carried out. Errors were shown in individual physical strength awareness arising from differences in predicted and actual measurement values. Three months later, subjects participated in a survey regarding whether or not falls had taken place and were examined for physical strength awareness. As a result of multiple logistic regression analysis, the usual functional reach test result $(\mathrm{p}<0.05)$ and physical strength awareness error $(\mathrm{p}<0.01)$ were both chosen as influences and factors in falling within the 3 month period. The recurrence adoption when the two factors were included was best. Furthermore, discriminant characteristic analysis indicated the possibility of distinguishing falls by errors in physical strength awareness at $6.5 \mathrm{~cm}$ (discriminant rate $91.7 \%$, sensitivity $80.9 \%$ ). It is thought that this test of physical strength awareness is useful information for predicting falling.

Key words: fall, elderly people, physical strength awareness

要旨 : 精度の高い転倒予測ツールの探求を目的にFunctional Reach Test（以下, FRT）を用いて高齢者の身体能力認識 の転倒への関与を検討した。対象は日常生活に支障のない健常高齢者88名とした。各被験者にFRTの予測值を申告さ せた後, 実際の計測を行い, 予測值と実測值の差から個々の身体能力認識誤差を求めた。その後 3 ケにわたり転倒の 有無に関する聞き取り調査を実施し, 身体能力認識の転倒への関与について検討した。多重ロジスティック分析の結 果，3ケ月以内の転倒に影響を及ぼす因子として，従来のFRT（ $\mathrm{p}<0.05 ）$ と身体能力認識誤差 $(\mathrm{p}<0.01)$ が選択され， 2項目投入時の回帰の適合が最良であった。判別特性分析では $6.5 \mathrm{~cm}$ の身体能力認識誤差を境として良好に転倒の有無 を判別可能であった（判別的中率 $91.7 \%$ ・感度 $80.9 \%$ )。このことから，身体能力認識は転倒を予測する有益な情報に なると考えられた。

キーワード：転倒，高齢者，身体能力認識

1) 山形医療技術専門学校 理学療法学科：山形県山形市大字前明石字水下367（勇990-2352） TEL 023-645-1571

2) 山形大学大学院医学系研究科医学専攻神経機能統御学講座 3) 尾花沢病院 リハビリテーション科

4) 弘前大学医学部保健学科

受付日 2004年8月25日 受理日 2004年10月12日 


\section{I. 緒 言}

高齢者の転倒は外傷や骨折を引き起こすばかりでな く, 時として死を引き起こす現象でもある1)。また, 死に 至らないまでも寝たきりを招く原因にもなりうる2)。これ は転倒後症候群と称され, 再転倒の恐怖のあまり行動や 日常生活活動範囲が極度に狭小化することにより高齢者 を虚弱に至らせるためである3)。このように高齢者の転倒 は, 高齢者の生命やその後の日常生活動作（ADL）なら びに生活の質（QOL）に重大な影響をおよぼす因子とし て捉えることができる。また，高齢者の転倒に由来する 保健・医療・福祉サービス利用は財政上の大きな問題で もある1)。そのため, この問題は高齢者に限った問題だけ ではなく, 現代社会が抱える大きな社会的問題として考 えるべきであろう。

この転倒を引き起こす要因は内的要因と外的要因に大 別することができる4)。内的要因とは転倒者自身に由来す る因子であるのに対し, 外的因子とは転倒者自身に起因 しない環境などに由来する因子である。敷居につまづい て転んだ場合, 一般的には外的要因に起因して転倒が生 じたと解釈される。しかし，外的要因があったにせよ， それに対応する充分な内的要因を持ち合わせるか，ある いは自己の内的要因を適切に認知して異なる方略をとっ ていれば転倒は生じ得なかったかもしれない。つまり, 環境に対する身体機能が不適切であった場合, または自 己身体能力に対する認識が不適切であった場合に転倒が 生じるとも解釈できる。特に高齢者では加齢的要因によ り様々な諸機能が低下することが知られている5-11)。した がって，種々の環境に適応しうるだけの充分な内的要因 を持ち合わせるには限界があると思われる。そのため, 加齢的要因による身体能力の变化を適切に認識した上で パフォーマンスを遂行したか否かは高齢者の転倒発生を 左右する重要な要素になると考える。

そこで本稿では，より精度の高い転倒予測ツール構築 の探求を目的に, 自己身体能力認識の転倒への関与につ いて検討を行うこととした。また今回は転倒との関連性 も比較的高く, 臨床でも多く用いられているFunctional Reach Test ${ }^{12,13)}$ （以下，FRT）を用いるとともに，それら の変法から自己身体能力の認識を求めることとした。

\section{II. 対 象}

3地区で行われた山形県O市主催の転倒予防教室に参 加した日常生活に支障のない健常高齢者91名を対象とし た。対象者の詳細については表1に示寸通りである。条件

\begin{tabular}{|c|c|c|}
\hline \multicolumn{2}{|l|}{ 項目 } & $\mathrm{n}=91$ \\
\hline \multicolumn{2}{|l|}{ 年齢 } & $80.6 \pm 6.9$ 歳 \\
\hline \multirow[t]{2}{*}{ 性別 } & 男性 & 25 名 $(27.5 \%)$ \\
\hline & 女性 & 66 名 $(72.5 \%)$ \\
\hline \multicolumn{2}{|c|}{ 過去 6r月内の転倒経験者 } & 13 名 $(14.3 \%)$ \\
\hline
\end{tabular}

として運動障害や感覚障害ならびに痴呆を有する者は対 象から除外した。全高齢者中13名が過去6r月以内に数回 の転倒を経験していた。この際の転倒の定義はGibsonに よる「本人の意思からではなく，地面またはそれより低


全例とも右利きであった。すべての対象者に同意を得た 後，測定を開始した。

\section{III. 方 法}

\section{FR測定值と身体能力認識誤差の測定}

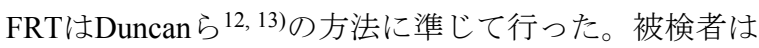
白板に垂直で, 床面のスタートラインに足先を合わせて 足幅を肩幅程度に開いた立位とした。白板にメジャーを 貼付し,メジャーの目盛り下には拡大した印を付けて被 検者が目盛りを認識できるよう配慮した。被検者には右 上肢の手指伸展 - 手関節中間 - 前腕回内 - 肘関節伸展 · 肩関節 $90^{\circ}$ 屈曲位をとらせ，この肢位を測定開始肢位と した。検者は測定開始肢位における第3指尖と一致する点 を被検者に伝え, 可能な限り前方にリーチした際に到達 すると予測される第3指尖の位置を答えさせた (予測值)。 この際，予行練習は一切行わず，検者がデモンストレー ションを行って十分に理解してもらった後に予測值を回 答させた。回答はmm単位で行わせ, 被検者の答えた位置 は検者が指を差し, 被検者が予想している位置と相違が ないか確認した。リーチ寸る際には足底を床面に接地さ せ，体幹の回旋を行わないことを条件とした。最大リー チ下での肢位保持時間は5秒とし，この際の第3指尖到達 位置を最大リーチ位として $\mathrm{mm}$ 単位で記録した (実測值)。 この一連の過程を遂行できた際の值を測定值として採用 した。実測值から測定開始肢位までの距離をFR測定值, 予測值と実測值の距離の絶対值を身体能力認識誤差と定 義した。測定中は転倒がないように十分な配慮を行って 測定を実施した。

2. 転倒の聞き取り調査 測定実施日より3ケ月間の転倒の有無に関する後方質 
問法での聞き取り調査を実施した。聞き取りは1ヶ月ごと に実施し，同居の場合は可能な限り同居者への聞き取り も行った。聴取内容は転倒の有無とし, 転倒の定義は Gibsonによる定義14,15) とした。なお，対象者が在住する 地域で聞き取り調査を実施した 3 ケ間（4～6月）に積雪 などはなかった。

\section{3. データ解析}

調査期間中の転倒の有無を従属変数, FR測定值ならび に身体能力認識誤差の 2 項目を独立変数として多重ロジ スティック回帰分析を行った。身体能力認識誤差が3 月 以内の転倒に有意な項目として選択された場合は, 3 ケ月 間に転倒があった者を転倒群, 転倒がなかった者を非転 倒群に分類し, 判別特性分析を用いて両群を最適に分類 するためのcut off值を求めた。この研究での有意水準は5 \%とし, 統計解析はStat Flex for Windowsを用いて行った。

\section{IV. 結 果}

調査を行った 91 名中, 3 名が調査期閒の3ケ月以内に脳 血管障害の発症や死去により調査継続が困難であった。 したがって，この3名は対象から除外して解析することと した。

継続調査が可能であった 88 名中，21名（23.9\%）が3ケ 月間の調査期間中に転倒を経験していた。転倒回数の内 訳は表2に示す通りである。

得られたFR測定值と身体能力認識誤差の平均值は表3 に示す通りである。多重ロジスティック回帰分析に先立

表2 3ケ月間における転倒回数の内訳

\begin{tabular}{cc}
\hline 転倒回数 & \multicolumn{1}{c}{ 人数 } \\
\hline なし & 67 名 $(76.1 \%)$ \\
1 回 & 7 名 $(8.0 \%)$ \\
2 回 & 5 名 $(5.7 \%)$ \\
3 回 & 2 名 $(2.3 \%)$ \\
4 回 & 3 名 $(3.4 \%)$ \\
5 回以上 & 4 名 $(4.5 \%)$ \\
$\mathrm{n}=88$ &
\end{tabular}

表3 FR測定值と身体能力認識誤差の平均值

\begin{tabular}{cc}
\hline FR 測定值 & 身体能力認識誤差 \\
\hline $15.0 \pm 6.1$ & $6.1 \pm 3.1$ \\
\hline
\end{tabular}

単位; $\mathrm{cm}$
ち, 独立変数である2項目に多重共線性がないか確認する ためにスピアマンの順位相関係数を求めた。その結果, 両項目間の相関係数はr $=0.20(\mathrm{p}<0.01)$ であった。この ことから, 両変数間に多重共線性があるとは考えられず, 両変数を独立変数として解析することに問題がないと判 断した。

多重ロジスティック回帰分析を用いた検討では, 3ケ月 以内の転倒に影響を及ぼす因子として, FR測定值 $(\mathrm{p}<$ 0.05) と身体能力認識誤差 $(\mathrm{p}<0.01)$ の両変数が選択さ れた。また，両変数を選択した際のAIC（赤池の情報量 基準）は個々の変数を単独で投入した時よりも小さい值 を示し, 回帰の適合が最良であった（2変数投入時 $\mathrm{AIC}=$ 66.2, $\mathrm{AIC}$ 減少量 $=6.0$ )。

3 ケ月間に転倒があった者を転倒群, 転倒がなかった者 を非転倒群に分類した判別特性分析では， $6.5 \mathrm{~cm}$ の身体 能力認識誤差を境として良好に転倒の有無を判別するこ とが可能であった（判別的中率 $91.7 \%$ ・感度 $80.9 \%$ ）。ち なみに, FR測定值では $14.5 \mathrm{~cm}$ 境に比較的良好に転倒の 有無を判別できた（判別的中率 $78.8 \%$ ・感度 $60.2 \%$ )。

\section{V. 考 察}

FRTは高齢者のバランスを測定するパフォーマンステ ストとして開発されたものである12,13)。これは高齢者の 転倒との相関も高く，簡便な評価であることから臨床で も幅広く活用されている。Duncanらは217名の高齢者を対 象とした前向き研究で, FR測定值6インチ $(15 \mathrm{~cm})$ 以下 の者が6ケ月以内に転倒するオッズ比をそれ以上の者と 比較して 4.0 と報告している11)。今回の検討におけるFR測 定值では $14.5 \mathrm{~cm}$ を境に比較的良好に転倒の有無を判別す ることが可能であった。このことを考慮すれば，今回の 結果はある程度の妥当性があるものと考えられる。

今回の結果では，一般的に指標とするFR測定值に身体 能力認識誤差を加えて転倒を予測する方が最良であるこ とが分かった。このFRTを動作として考えた場合，支持 基底面内での自発的な重心移動などの動的バランスをと ることが要求される16)。そのため，このような総合的能 力を含むFRTが高齢者の転倒と相関が高いことはおおよ そ理解できる。しかし，高齢者の中にはこれらの総合的 能力があるにせよ, この能力を不適切に認識しているこ とで転倒が生じている者もいるであろう。しかし, 現行 のFRTでは動的バランスの総合的評価は可能であるが, 上述した要素の評価はできない。したがって, 現行のFRT における動的バランスの総合的評価に加え, ある一定以 上の動的バランス能力を要しても, 不適切な身体能力認 
識により生じたと考えられる転倒も評価できたことがこ のような結果を導いたと考察する。このことは, 動的バ ランスはもちろんのこと, 身体能力認識も転倒に関与す る重要な因子であることを示唆するものと考える。さら に, この身体能力認識誤差は $6.5 \mathrm{~cm}$ を境として良好に転 倒群と非転倒群を大別することが可能であった。また， FR測定值では先行研究 ${ }^{11)}$ と類似して $14.5 \mathrm{~cm}$ を境に転倒 群と非転倒群を大別が可能であった。そのため, FR測定 值が $15 \mathrm{~cm}$ に満たない, または $6.5 \mathrm{~cm}$ 以上の身体能力認識 誤差を有する者では特に転倒の危険性が高くなると推測 される。

一方, 今回の結果は転倒の予測に留まらず，それを予 防するための介入的側面でも応用することが可能である と考える。当然のこととして, 加齢による一次退行は万 人に起こる現象であり，転倒を引き起こすと考えられる 内的要因を軽減するには限界があると思われる。この身 体能力認識も様々な諸機能に裏打ちされたものであり改 善寸るには限界があるだろう。しかし，青年期に好発す るアキレス腱断裂のように，過去の記憶による誤った身 体能力の認識から無理なパフォーマンスを行い, 転倒が 生じているものもあると考える17)。そのため，このよう な誤った認識を修正するだけでも何らかの転倒予防効果 は期待できるものと考える。具体的な介入による改善効 果がどの程度まで期待できるかは疑問であるが，この身 体能力認識と転倒との関連性が高いことを考えれば，こ れに対する何らかの働きかけは必要であろう。

転倒は課題を遂行寸る上で生じる身体機能の環境への 不適応や, 自己身体能力に対する不適切な認識の結果か ら明らかになるものであり, それらを完全に予測するこ とは困難であると考えられる6。しかし，この高齢者の転 倒は現代社会が抱える社会問題であり避けて通ることは できない。今後も様々な角度から高齢者の転倒に関する 検討を行っていきたいと考える。

\section{引用文献}

1) 鈴木友理子, 安村誠司, 深尾 彰: 高齢者の転倒・骨折をめ ぐって。 日本醫事新報, 2000，3975: 15-20.

2) 新野直明: 高齢者の車云倒とは. 綜合臨牀, 1999, 48: 1583-1584.

3) 眞野行生, 中根理江: 高齢者の歩行障害と転倒要因. Clinical Rehabilitation, 1998, $7: 243-247$.

4) 岡本五十雄: リハビリテーションとして転倒をどうとらえる か. Clinical Rehabilitation, 1998, $7: 272-276$.

5) 太田美穂, 武藤芳照, 上岡洋晴・他 : 高齢者の転倒の実態と 身体特性との関連. 日本醫事新報, 1997, 3837:26-32.

6) 星 文彦: 高齢者の加齢変化と転倒要因. PT ジャーナル, 2002, 36 : 307-314.

7) 折茂 肇 (編) : 新老年医学. 東京大学出版会, 東京, 1999, pp125-536.

8) Dargent-Molina P, Favier F, Grandjean H, et al.: Fall-related factors and risk of hip fracture; The EPIDOS prospective study. Lancet, 1996, 348: 145-149.

9) Ring C, Nayak US, Isaacs B: Balance function in elderly people who have and who have not fallen. Arch Phys Med Rehabil, 1988, 69: 261.

10) 内山 靖: 高齢者の平衡機能と転倒. 理学療法, 2001, 18 : 853-863.

11) 琉子友男: 若年者と高齢者の体力の違い. Clinical Rehabilitation, 2000, 9 : 323-328.

12) Duncan PW, Weiner DK, Chandler J, et al.: Functional reach: a new clinical measure of balance. J Gerontol, 1990, 45: M192-197.

13) Duncan PW, Studenski S, Chandler J, et al.: Functional reach: predictive validity in a sample of elderly male veterans. J Gerontol, 1992, 47: M93-98.

14) Gibson MJ: Improving the Health of Older People. Oxford Univ Press, England, 1990, pp296-315.

15) 上岡洋晴, 武藤芳照 : 転倒の病態生理. 理学療法, 2000, 17 : 1042-1047.

16) 須藤真史, 藤田由香, 貴田貴子 - 他 : 脳卒中片麻㾝に対する 理学療法後下と判定. 理学療法ジャーナル，2001，35：879884 .

17) 山下敏彦, 石井清一: スポーツ傷害. 越智隆弘, 菊地臣一 (編)，金原出版，東京，1990，pp49-57. 